\title{
RFC4 wt Allele
}

National Cancer Institute

\section{Source}

National Cancer Institute. RFC4 wt Allele. NCI Thesaurus. Code C158526.

Human RFC4 wild-type allele is located in the vicinity of $3 q 27.3$ and is approximately $17 \mathrm{~kb}$ in length. This allele, which encodes replication factor $C$ subunit 4 protein, plays a role in DNA replication. 